\title{
ЗНАЧЕННЯ ПРОЦЕСІВ ВІЛЬНОРАДИКАЛЬНОГО ОКИСНЕННЯ ТА АНТИОКСИДАНТНОГО ЗАХИСТУ В БРОНХАХ МОРСЬКИХ СВИНОК У ПАТОГЕНЕЗІ ЕКСПЕРИМЕНТАЛЬНОЇ БРОНХІАЛЬНОЇ АСТМИ Й ЕКСПЕРИМЕНТАЛЬНОЇ ВИРАЗКОВОЇ ХВОРОБИ ШЛУНКА ТА ЇХ ФАРМАКОЛОГІЧНА КОРЕКЦІЯ
}

\footnotetext{
Вступ. Лікарі практичної охорони здоров'я досить часто спостерігають різне поєднання захворювань, у тому числі трапляються випадки бронхіальної астми і виразкової хвороби шлунка, які, безперечно, обтяжують перебіг цих недуг та лікування.

Мета дослідження - вивчити стан прооксидантної і антиоксидантної систем у бронхах морських свинок за умов розвитку експериментальної бронхіальної астми (ЕБА) та експериментальної виразкової хвороби шлунка (ЕВХШ) до лікування і після застосування антиоксиданта тіотриазоліну.

Методи дослідження. Експериментальне дослідження проводили на 64 морських свинках (самцях) масою 180-220 2, яких поділили на 6 груп по 9 тварин у кожній, крім 1-ї (10 тварин). До 1-ї групи (контрольноі) входили інтактні морські свинки, до 2-ї- тварини з ЕБА та ЕВХШ (5-та доба), до 3-ї - морські свинки на 19-ту добу поєднаного модельного процесу, до 4-ї- тварини з ЕБА й ЕВХШ (26-та доба), до 5-ї- морські свинки на 33-тю добу ЕБА та ЕВХШ до лікування, до 6-ї- тварини з ЕБА й ЕВХШ після застосування тіотриазоліну внутрішньом'язово в дозі 100 мг на 1 кг маси щодня впродовж 10 діб (з 23-ї до 33-і) експерименmy.

Результати й обговорення. Результати біохімічних досліджень свідчать про те, що за умов розвитку ЕБА та ЕВХШ спостерігали характерні ознаки розвитку оксидантного стресу, що проявлявся надмірним утворенням продуктів ліпопероксидації на тлі депресії ензимної ланки антиоксидантної системи. Введення тіотриазоліну призводило до суттєвого зниження вмісту дієнових кон'югатів і малонового діальдегіду в бронхах - відповідно, на 44,3 \% ( $\left.p_{1} \leq 0,05\right)$ та 38,5\% $\left(p_{1} \leq 0,05\right)$, а також підвищення рівня супероксиддисмутази, каталази і глутатіонпероксидази в бронхах - відповідно, на 32,1 \% (p $\left.p_{1} \leq 0,05\right), 38,3$ \% $\left(p_{1} \leq 0,05\right)$ та 35,1 \% $\left(p_{1} \leq 0,05\right)$ порівняно з групою тварин, яких не піддавали впливу цього препарату.

Висновок. Результати проведеного впродовж 10 діб лікування тіотриазоліном показали достовірне пригнічення надмірної активності ліпопероксидації з одночасним підвищенням активності антиоксидантної системи в морських свинок при експериментальній бронхіальній астмі та експериментальній виразковій хворобі шлунка.
}

КЛЮЧОВІ СЛОВА: бронхіальна астма; виразкова хвороба шлунка; вільнорадикальне окиснення; антиоксидантний захист; тіотриазолін.

ВСТУП. Бронхіальна астма як хронічна рецидивна хвороба залишається актуальною медичною, соціальною, економічною проблемою сучасного суспільства та галузі охорони здоров'я [1]. Поширеність у різних країнах коливається від 1 до 16 \%. Науковці та лікарі-практики досягли значних успіхів у вивченні бронхіальної астми, у тому числі в дослідженні патогенезу даного захворювання, однак, за даними епідеміологічних досліджень, у середньому половина пацієнтів не може досягти або довгостроково підтримувати контроль бронхіальної астми. Якщо при цьому врахувати найвищу поширеність даного (с) М. А. Колішецька, 2021. захворювання та пов'язані з ним витрати, не викликає подиву той фракт, що до пошуку нових ефрективних методів лікування бронхіальної астми докладають значних зусиль і виділяють на це великі кошти [2].

Лікарі практичної охорони здоров'я досить часто спостерігають різне поєднання захворювань, у тому числі трапляються випадки бронхіальної астми і виразкової хвороби шлунка, які, безперечно, обтяжують перебіг цих недуг та лікування [3].

На сьогодні невивченим залишається питання, що стосується процесів вільнорадикального окиснення та антиоксидантного захисту. 
В цій експериментальній роботі було вивчено один із молекулярних механізмів ушкодження клітин - пероксидне окиснення ліпідів (ПОЛ) [4, 5]. На думку багатьох авторів, посилення процесів ПОЛ та їх ушкоджувальна дія на мембрани тісно взаємопов'язані з іншими мембранодеструктивними фракторами: дефіцитом енергії, ацидозом, ліполізом, виходом лізосомальних ензимів, арахідоновим каскадом [5]. Для корекції порушених показників застосовано вітчизняний лікарський препарат "Тіотриазолін”, антиоксидантна дія якого полягає в тому, що він активує антиоксидантні ензими - супероксиддисмутазу (СОД), каталазу (КТ), глутатіонпероксидазу (ГПО), а також сприяє більш економній витраті ендогенного антиоксиданта $\alpha$-токофреролу, гальмує утворення проміжних та кінцевих продуктів ПОЛ - дієнових кон'югатів (ДК), трієнкетонів і малонового діальдегіду (МДА).

Мета дослідження - вивчити стан прооксидантної і антиоксидантної систем у бронхах морських свинок за умов розвитку експериментальної бронхіальної астми (ЕБА) та експериментальної виразкової хвороби шлунка (ЕВХШ) до лікування і після застосування антиоксиданта тіотриазоліну.

МЕТОДИ ДОСЛІДЖЕННЯ. Експериментальне дослідження проводили на 64 морських свинках (самцях) масою 180-220 г, яких поділили на 6 груп по 9 тварин у кожній, крім 1-ї (10 тварин). До 1-ї групи (контрольної) входили інтактні морські свинки, до 2-ї - тварини з ЕБА та ЕВХШ (5-та доба), до 3-ї- морські свинки на 19-ту добу поєднаного модельного процесу, до 4-ї - тварини з ЕБА й ЕВХШ (26-та доба), до 5-ї - морські свинки на 33-тю добу ЕБА та ЕВХШ до лікування, до 6-ї - тварини з ЕБА й ЕВХШ після застосування тіотриазоліну внутрішньом'язово в дозі 100 мг на 1 кг маси щодня впродовж 10 діб (з 23-ї до 33-ї) експерименту. 3 метою детального аналізу й інтерпретації показників прооксидантної та антиоксидантної систем у різні доби експерименту умовно виділено 2 періоди розвитку ЕБА й ЕВХШ: ранній (5-та і 19-та доби експерименту) та пізній (26-та і 33-тя доби).

Експериментальну модель бронхіальної астми відтворювали на морських свинках за методом В. І. Бабича (1979), виразкову хворобу шлунка моделювали за методом В. І. Комарова [6]. Усіх експериментальних тварин утримували в стандартних умовах віварію Львівського національного медичного університету імені Данила Галицького. Евтаназію морських свинок проводили шляхом декапітації з дотриманням Європейської конвенції про захист хребетних тварин, що використовуються для дослідних та інших наукових цілей.

Стан вільнорадикального окиснення ліпідів у бронхах визначали за вмістом дієнових кон'югатів (за методом В. Б. Гаврилова, М. І. Мишкорудної, 1989 [7]) і малонового діальдегіду (за методом Е. Н. Коробейникової, 1989 [8]). Ступінь активності антиоксидантної системи (АОС) оцінювали за вмістом ензимів - супероксиддисмутази (за методом R. Fried, 1975 [9]), каталази (за методом R. S. Holmes, C. J. Masters, 1970 [10]), глутатіонпероксидази (за методом О. Г. Архипової, 1988 [11]). Статистичне опрацювання одержаних даних здійснювали за методом Стьюдента.

РЕЗУЛЬТАТИ Й ОБГОВОРЕННЯ. АНаЛіЗ даних проведеного дослідження свідчить про те, що у морських свинок з ЕБА та ЕВХШ до початку лікування мала місце виражена активація ПОЛ залежно від тривалості патологічного процесу. Так, було зафріксовано підвищення вмісту дієнових кон'югатів у бронхах на 5-ту і 19-ту доби поєднаних патологій, відповідно, на 44,5\% $(p<0,05)$ та $68,8 \%(p<0,05)$ порівняно $з$ контрольною групою. Результати вивчення вмісту малонового діальдегіду в бронхах дали можливість виявити його аналогічне поступове зростання на $32,4 \%(p<0,05)$ на 5-ту добу експерименту і на 59,2 \% $(p<0,05)$ на 19-ту добу ЕБА й ЕВХШ порівняно $з$ тваринами 1-ї групи, що вказувало на стимуляцію прооксидантної системи таїї інтенсисрікацію в міру розвитку патологічних процесів.

Підвищення цих показників відзначали і в пізній період даного експерименту, а саме на 26-ту добу розвитку комбінованої патології виявлено збільшення вмісту ДК на 102,3 \% $(\mathrm{p} \leq 0,05)$ проти контрольної групи. Пізніше, на 33-тю добу ЕБА та ЕВХШ, спостерігали ще суттєвіше зростання рівня ДК у бронхах - на 166,3\% $(p \geq 0,05)$ проти 1-ї групи морських свинок, що свідчило про ще більшу інтенсивність окисних реакцій з надмірним накопиченням у бронхах продуктів вільнорадикального окиснення.

Результати дослідження показали, що вміст МДА в бронхах також зростав на 85,3\% $(p \leq 0,05)$ на 26-ту добу ЕБА та ЕВХШ і залишався стабільно вищим на $98,2 \%(p \leq 0,05)$ порівняно 3 контрольною групою тварин, це вказувало на прискорення процесів ліпопероксидації.

На тлі активізації пероксидних процесів у бронхах морських свинок при модельній коморбідній патології виявлено значні зміни в системі антиоксидантного захисту. Зокрема, в усіх групах достовірно змінилась активність супероксиддисмутази, каталази і глутатіонпероксидази.

На 5-ту добу експерименту активність СОД, КТ, ГПО підвищилась, відповідно, на 43,5 \% 
(p $\leq 0,05), 27,8 \%(p \leq 0,05), 19,2 \%(p \leq 0,05)$ щодо контрольної групи. Починаючи з 19-ї доби ЕБА та ЕВХШ, активність досліджуваних ензимів знижувалась, а саме рівень СОД, КТ, ГПО зменшився, відповідно, на 28,3 \% ( $\mathrm{p} \leq 0,05), 27,8 \%$ $(p \leq 0,05), 37,9 \%(p \leq 0,05)$ проти контрольної групи, що вказувало спочатку на стимуляцію, а згодом на виснаження АОС.

Продовжуючи дослідження, спостерігали подальшу суттєву регресію маркерів антиоксидантної системи. Пізній період формування ЕБА та ЕВХШ супроводжувався зниженням рівня СОД на 28,8 \% ( $\leq 50,05)$ на 26-ту добу експерименту і на 43,9\% $(p \leq 0,05)$ - на 33-тю порівняно 3 1-ю групою морських свинок. Зміни аналогічного характеру відзначали і щодо решти показників, a саме зменшення рівня КТ на $31,6 \%(p \leq 0,05)$ i
$46,2 \%(p \leq 0,05)$, ГПО - на 47,5\% $(p \leq 0,05)$ та 54,5 \% ( $p \leq 0,05)$, відповідно, на 26-ту і 33-тю доби експерименту порівняно з контрольною групою, що характеризувало подальшу супресію AOC у бронхах.

Введення тіотриазоліну призводило до суттєвого зменшення вмісту ДК і МДА в бронхах відповідно, на 44,3\% $\left(p_{1} \leq 0,05\right)$ та 38,5\% $\left(p_{1} \leq 0,05\right)$ порівняно з групою тварин, яких не піддавали впливу цього препарату. Результати проведеного лікування показали еорективність та підвищення активності АОС. Так, після застосування тіотриазоліну рівень СОД у бронхах збільшився на $32,1 \%\left(p_{1} \leq 0,05\right), \mathrm{KT}$ - на 38,3\% $\left(p_{1} \leq 0,05\right)$, істотно зросла активність ГПО - на 35,1\% $\left(p_{1} \leq 0,05\right)$ проти морських свинок, яким лікування не проводили (рис.).

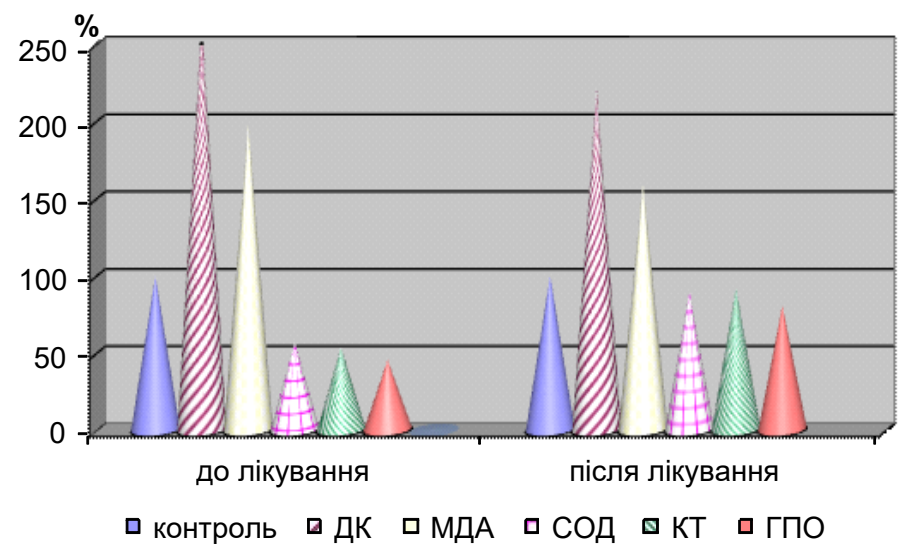

Рис. Вплив тіотриазоліну на рівень пероксидного окиснення ліпідів - антиоксидантної системи в легенях морських свинок у динаміці фрормування експериментальної бронхіальної астми та експериментальної виразкової хвороби шлунка.

ВИСНОВКИ. За умов розвитку експериментальної бронхіальної астми та експериментальної виразкової хвороби шлунка спостерігають характерні ознаки розвитку оксидантного стресу, що проявляється надмірним утворенням продуктів ліпопероксидації на тлі депресії ензимної ланки антиоксидантної системи. Результати проведеного впродовж 10 діб лікування тіотриазоліном показали достовірне пригнічення надмірної активності ліпопероксидації з одночасним підвищенням активності антиоксидантної системи в морських свинок при експериментальній бронхіальній астмі та експериментальній вираз- ковій хворобі шлунка. Це свідчить про його позитивний коригувальний ефект на зазначені вище показники порушених метаболічних процесів у комплексній терапії при експериментальній бронхіальній астмі та експериментальній виразковій хворобі шлунка.

Перспективи подальших досліджень. У подальшому заплановано дослідити вплив фрармакологічної корекції на прооксидантну й антиоксидантну системи в легенях морських свинок за умов розвитку експериментальної бронхіальної астми та експериментальної виразкової хвороби шлунка.

\section{СПИСОК ЛІТЕРАТУРИ}

1. Inhaled combined budesonide-formoterol as needed in mild asthma / P. O'Byrne, M. FitzGerald, E. Bateman [et al.] // NEJM. - 2018. - 378. - P. 18651876.

2. GINA2018. Updated 2018. - Access mode : www. ginasthma.org.
3. Регеда-Фурдичко М. М. Динаміка змін процесів ліпопероксидації та антиоксидантної системи в легенях у патогенезі розвитку експериментального контактного дерматиту / М. М. Регеда-Фурдичко // Здобутки клініч. та експерим. медицини. - 2019. - № 4. C. $106-110$ 
4. Nimse S. B. Free radicals, natural antioxidants, and their reaction mechanisms / S. B. Nimse, D. Pal // Rsc. Advances. - 2015. - 5, 35. - P. 27986-28006.

5 . The role of antioxidants in the chemistry of oxidative stress: Lipid peroxidation-mediated inflammation promotes cell apoptosis through activation of NFKB pathway in rheumatoid arthritis synovial cells / A. M. Pisoschi, A. Pop, G. Yin [et al.] // Mediators of Inflammation. - 2015. - 2015.

6. Гоженко А. І. Клініко-патогенетичне обґрунтування комплексної терапії ХОЗЛ і супутніх гастропатологій / А. І. Гоженко, Л. А. Ковальська, О.В.Кучер // Актуальні проблеми транспортної медицини. -2013. № 3 (33). - C. 88-94.

7. Гаврилов В. Б. Спектрофотометрическое определение содержания гидроперекисей липидов в плазме крови / В. Б. Гаврилов, М. И. Мишкорудная // Лабораторная диагностика ишемической болезни сердца. - К. : Здоровье, 1989. - С. 170-171.

8. Коробейникова Э. Н. Модисрикация определения продуктов ПОЛ в реакции с тиобарбитуровой кислотой / Э. Н. Коробейникова // Лаб. дело. - 1989. № 7. - C. 8-10.

9. Fried R. Enzymatic and non-enzymaticassay of superoxide ifilii / R. Fried // Biochemie. - 1975. - 57, No. 5. - P. 657-660.

10. Holmes R. S. Epigenetic interconversions of the multiple forms of mouse liver catalase / R. S. Holmes, C. J. Masters // FEBS Lett. -1970. -11, No. 1. - P. 45-48.

11. Определение активности пероксидазы в крови // Методы исследования в профпатологии / под ред. О. Г. Архиповой. - М. : Медицина, 1988. - С. 153.

\section{REFERENCES}

1. O'Byrne, P., FitzGerald, M., \& Bateman, E. (2018). Inhaled combined budesonide-formoterol as needed in mild asthma. NEJM, (378), 1865-1876.

2. GINA 2018. Updated 2018. Retrieved from: www. ginasthma.org.

3. Regeda-Furdychko, M.M. (2019). Dynamika zmin protsesiv lipoperoksydatsii ta antyoksydantnoi systemy $v$ leheniakh u patohenezi rozvytku eksperymentalnoho kontaktnoho dermatytu [Dynamics of changes in the processes of lipoperoxidation and antioxidant system in lungs in the pathogenesis of experimental contact dermatitis]. Zdobutky klinichnoi i eksperymentalnoi medytsyny - Achievements of Clinical and Experimental Medicine, 4, 106-110 [in Ukrainian].

4. Nimse, S.B., \& Pal, D. (2015). Free radicals, natural antioxidants, and their reaction mechanisms. Rsc. Advances., 5 (35), 27986-28006.

5. Pisoschi, A.M., Pop. A., \& Yin, G. (2015). The role of antioxidants in the chemistry of oxidative stress: et al. Lipid peroxidation-mediated inflammation promotes cell apoptosis through activation of NFKB pathway in rheumatoid arthritis synovial cells. Mediators of Inflammation, 2015.

6. Hozhenko, A.I., Kovalska, L.A., \& Kucher, O.V. (2013). Kliniko-patohenetychne obhruntuvannia kompleksnoi terapii KhOZL I suputnikh hastropatolohii [Clinical

and pathogenic grounds for complex therapy of ChOPD and concomitant gastropathology]. Aktualni problemy transportnoi medytsyny - Current Issues of Transport Medicine, 3 (33), 88-94 [in Ukrainian]

7. Gavrilov, V.B., \& Mishkorudnaya, M.I. (1989). Spektrofotometricheskoye opredeleniye soderzhanie gidroperikesey lipidov v plazme krovi [Spectrophotometric determination of lipid hydroperoxides in blood plasma]. Laboratornaya diagnostika ishemicheskoy bolezni serdtsa - Laboratory Diagnostics of Ischemic Heart Disease, Kyiv: Zdorovye [in Russian]

8. Korobeynikova, E.N. (1989). Modifikatsiya opredeleniya produktov POL $v$ reaktsii s tiobarbiturovoy kislotoy [Modification of determination of LP products in reaction with thiobarbituric acid]. Laboratornoe delo Laboratory Work, 7, 8-10 [in Russian].

9. Fried, R. (1975). Enzymatic and nonenzymatic assay of superoxide ifilli. Biochemie, 57 (5), 657-660.

10. Holmes, R. (1970). Epigenetic interconversions of the multiple forms of mouse liver catalase. FEBS Lett, 11 (1), 45-48

11. Arkhipova, O.H. (1988). Opredelenie aktivnosti peroksidazy v krovi. Metody issledovaniya $v$ profpatologii [Determination of the activity of peroxidase in the blood. Methods of research in occupational pathology]. Moscow: Meditsina [in Russian].

\section{ЗНАЧЕНИЕ ПРОЦЕССОВ СВОБОДНОРАДИКАЛЬНОГО ОКИСЛЕНИЯ И АНТИОКСИДАНТНОЙ ЗАЩИТЫ В БРОНХАХ МОРСКИХ СВИНОК В ПАТОГЕНЕЗЕ ЭКСПЕРИМЕНТАЛЬНОЙ БРОНХИАЛЬНОЙ АСТМЫ И ЭКСПЕРИМЕНТАЛЬНОЙ ЯЗВЕННОЙ БОЛЕЗНИ ЖЕЛУДКА И ИХ ФАРМАКОЛОГИЧЕСКАЯ КОРРЕКЦИЯ}

\section{Резюме}

Вступление. Врачи практического здравоохранения достаточно часто наблюдают различное сочетание заболеваний, в том числе встречаются случаи бронхиальной астмы и язвенной болезни желудка, которые, несомненно, отягощают течение этих недугов и лечение. 
Цель исследования - изучить состояние прооксидантной и антиоксидантной систем в бронхах морских свинок в условиях развития экспериментальной бронхиальной астмы (ЭБА) и экспериментальной язвенной болезни желудка (ЭЯБЖ) до лечения и после применения антиоксиданта тиотриазолина.

Методы исследования. Экспериментальное исследование проводили на 64 морских свинках (самцах) массой 180-220 2, которых разделили на 6 групп по 9 животных в каждой, кроме 1-й (10 животных). В 1-ю группу (контрольную) входили интактные морские свинки, во 2-ю - животные с ЭБА и ЭЯБЖ (5-е сутки), в 3-ю - морские свинки на 19-е сутки сочетанного модельного процесса, в 4-ю - животные с ЭБА и ЭЯБЖ (26-е сутки), в 5-ю - морские свинки на 33-е сутки ЭБА и ЭЯБЖ до лечения, в 6-ю - животные с ЭБА и ЭЯБЖ после применения тиотриазолина внутримышечно в дозе 100 мг на 1 кг массы ежедневно в течение 10 суток (с 23-х по 33-е) эксперимента.

Результаты и обсуждение. Результаты биохимических исследований свидетельствуют о том, что в условиях развития ЭБА и ЭЯБЖ наблюдали характерные признаки развития оксидантного стресса, который проявлялся избыточным образованием продуктов липопероксидации на фоне депрессии энзимного звена антиоксидантной системы. Введение тиотриазолина приводило к существенному снижению содержания диеновых конъюгатов и малонового диальдегида в бронхах - соответственно, на $44,3 \%\left(p_{1} \leq 0,05\right)$ и 38,5\% ( $\left.p_{1} \leq 0,05\right)$, а также повышению уровня супероксиддисмутазы, каталазы и глутатионпероксидазы в бронхах - соответственно, на 32,1\% $\left(p_{1} \leq 0,05\right), 38,3 \%\left(p_{1} \leq 0,05\right)$ и 35,1\% $\left(p_{1} \leq 0,05\right)$ по сравнению с группой животных, которых не подвергали воздействию этого препарата.

Вывод. Результаты проведенного в течение 10 суток лечения тиотриазолином показали достоверное подавление чрезмерной активности липопероксидации с одновременным повышением активности антиоксидантной системы в морских свинок при экспериментальной бронхиальной астме и экспериментальной язвенной болезни желудка.

КЛЮЧЕВЫЕ СЛОВА: бронхиальная астма; язвенная болезнь желудка; свободнорадикальное окисление; антиоксидантная защита; тиотриазолин.

M. A. Kolishetska

DANYLO HALYTSKY LVIV NATIONAL MEDICAL UNIVERSITY

\section{THE SIGNIFICANCE OF FREE RADICAL OXIDATION AND ANTIOXIDANT PROTECTION IN GUINEA PIG BRONCHI IN THE PATHOGENESIS OF EXPERIMENTAL BRONCHIAL ASTHMA AND EXPERIMENTAL STOMACH ULCER AND THEIR PHARMACOLOGICAL CORRECTION}

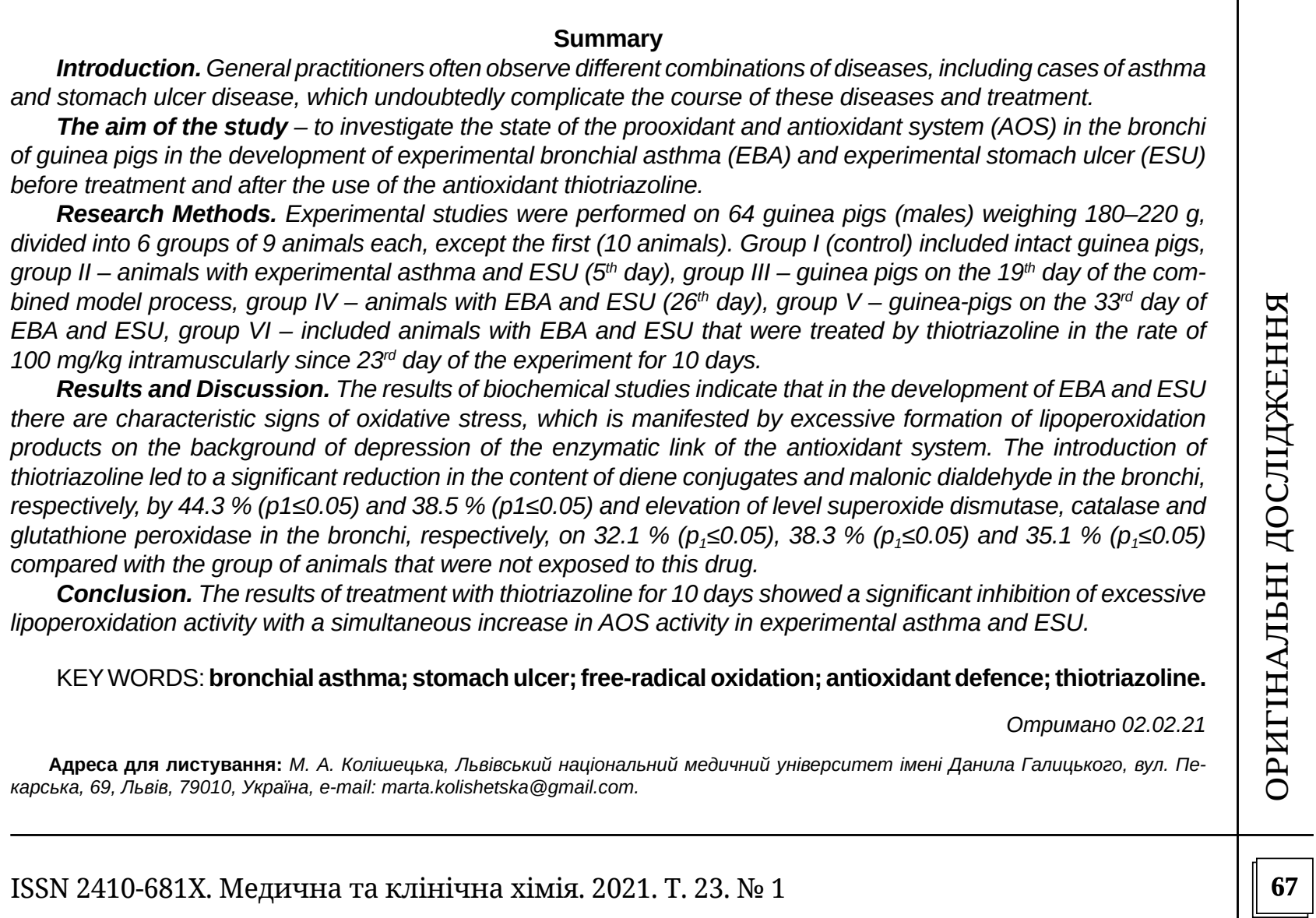

